\title{
Effects of single dose compared with three days' prednisolone treatment of healthy volunteers: contrasting effects on circulating lymphocyte subsets
}

\author{
G D Pountain, M T Keogan, B L Hazleman, D L Brown
}

\begin{abstract}
Aims-To investigate the effects of longer term corticosteroid treatment on circulating lymphocyte subsets. Methods-Prednisolone (20 mg daily) was given to 12 healthy volunteers in a single morning dose for three days. Circulating lymphocyte subsets were measured by flow cytometry after whole blood lysis.

Results-Seven hours after the first dose of prednisolone there was a significant fall in absolute numbers of lymphocytes, $T$ cells, CD4 + and CD8 + cells, and $B$ cells. The percentage of $T$ cells fell significantly, due to a fall in percentage of CD4 + cells. In contrast to the seven hour findings, at 72 hours there was a significant rise in absolute numbers of lymphocytes, T cells, CD4 +, CD8 +, and $B$ cells. This trend was already apparent by 24 hours. The percentage of CD4+ cells was significantly raised at 72 hours, while that of $\mathrm{CD8}+$ cells had fallen significantly. The percentage of natural killer cells had fallen at 72 hours; that of $B$ cells remained increased at 72 hours. Conclusions-These findings show that corticosteroid treatment causes significant changes in lymphocyte subsets, and that such changes must be considered when designing studies of lymphocyte subsets during illness.
\end{abstract}

(F Clin Pathol 1993;46:1089-1092)

In a study of $T$ cell subsets in polymyalgia rheumatica and giant cell arteritis $(\text { PMR/GCA })^{1}$ we observed that once prednisolone treatment had been started, total numbers of $T$ cells rose and the percentage of CD8 + cells fell significantly. Lymphocyte subsets were normal before treatment compared with age matched controls. This suggested that the prednisolone, not the PMR/GCA, was responsible for the $T$ cell changes. We therefore decided to investigate further the effects of prednisolone treatment, using healthy volunteers.

Some of the short-term effects of corticosteriods on lymphocyte subsets have been documented. $\mathrm{Yu}^{2}$ and Fauci $^{3}$ showed lymphopenia to be maximal 4-6 hours after a single dose of corticosteroids given to healthy volunteers. With the advent of monoclonal antibodies and flow cytometry, ten Berge et $a l^{4}$ documented reduced $\mathrm{T}$ cells, particularly
OKT 4 + cells, at six hours after a single dose of prednisolone given to normal volunteers compared with controls. They also showed that by 24 hours this effect had disappeared with a slight "rebound effect"-OKT4 + and OKT 8 + cells were slightly increased by 24 hours, though this was not significant. This study did not look at the effects of longer term administration of prednisolone.

Similarly, Tonnesen et al $^{5}$ infused cortisol into healthy volunteers for five hours and showed reduced lymphocytes, OKT3+, OKT 4 + and OKT 8 + cells by two hours compared with controls. These changes persisted 15 minutes after the cortisol infusion had been discontinued, but were not monitored after that time.

Hogevold et $a l^{6}$ gave high dose methylprednisolone preoperatively and four and 12 hours after total hip replacement. After this short duration of corticosteroids, they showed reduced total $T$ cells and helper and suppressor cells, compared with control patients, at 20 hours ( = eight hours after the last dose of methylprednisolone).

The effects on $T$ cells of longer term corticosteroid administration have not been documented in healthy people, although changes occurring in patients treated with corticosteroids have been described. Ferrari et $a l^{7}$ reported increased lymphocytes, including increased absolute numbers of $T$ cells, CD4 + and CD8 + cells, after four weeks of corticosteroid treatment in idiopathic thrombocytopenic purpura (ITP). The percentages of CD4 + and CD8 + cells were not significantly changed. In this study, therefore, the longer term effects of corticosteroid seem to be quite different from the acute effects a few hours after a single dose.

Fauci ${ }^{8}$ described the effects of seven days of cortisone administration in guinea pigs, as well as the acute effects of a single dose of hydrocortisone. At both stages there was a fall in lymphocyte and $T$ cell numbers. The observation of reduced lymphocytes and $\mathrm{T}$ cells four hours after the hydrocortisone corresponds to the acute effects seen in human volunteers. ${ }^{2-5}$ But the seven day effects in Fauci's guinea pigs $^{8}$ were at odds with the effects in Ferrari's patients with ITP, where after four weeks of corticosteroids lymphocytes and $\mathrm{T}$ cells had risen. ${ }^{7}$ The difference between these studies might be a species effect, or the effects of corticosteroids in patients might have been modified by the disease process itself.

Although the nature of the acute changes 
Effects on circulating lymphocyte subsets of prednisolone EC $20 \mathrm{mg}$ for three days in healthy volunteers $(n=12)$

\begin{tabular}{|c|c|c|c|c|c|c|}
\hline & Baseline & 7 hours & 24 hours & 48 hours & $\begin{array}{l}\text { (55 hours) } \\
(n=4)\end{array}$ & 72 hours \\
\hline Lymphocytes $\left(\times 10^{9} / 1\right)$ & 2.09 & $1 \cdot 02^{\star \star}$ & 2.53 & $2 \cdot 65$ & $(2 \cdot 35)$ & $3 \cdot 39 \star \star$ \\
\hline $\left.10^{\circ} / 1\right)$ & 1.5 & 0.5 & 1 . & $2 \cdot 0$ & $(1.71)$ & $2 \cdot 54^{\star \star}$ \\
\hline $\mathrm{CD} 4+$ cells $\left(\times 10^{9} / 1\right)$ & 1.06 & $0 \cdot 36^{\star \star}$ & 1.30 & $1 \cdot 42$ & $(1.01)$ & $1 \cdot 61^{\star \star}$ \\
\hline CD $8+$ cells $\left(\times 10^{\circ} / 1\right)$ & 0.58 & $0 \cdot 41^{\star \star}$ & 0.67 & 0.59 & $(0.69)$ & $0.83^{\star \star}$ \\
\hline $\begin{array}{l}\text { Activated T cells } \\
\left(\times 10^{\circ} / 1\right)(\mathrm{n}=9)\end{array}$ & $0 \cdot 11$ & $\begin{array}{c}0.07 \mathrm{NS} \\
(\mathrm{p}=0.75)\end{array}$ & $0 \cdot 17$ & $0 \cdot 13$ & - & $\begin{array}{c}0.14 \mathrm{NS} \\
(p=0.063)\end{array}$ \\
\hline NK cells $\left(\times 10^{\circ} / 1\right)$ & $0 \cdot 32$ & $0.35 \mathrm{NS}$ & 0.33 & 0.23 & $(0.45)$ & $0.34 \mathrm{NS}$ \\
\hline $\mathrm{B}$ cells $\left(\times 10^{\circ} / 1\right)$ & $0 \cdot 23$ & $0 \cdot 15^{\star}$ & $0 \cdot 27$ & 0.34 & $(0.32)$ & $0.53^{\star \star}$ \\
\hline $\begin{array}{l}\mathrm{T} \text { cells } \\
\text { (\% of lymphocytes) }\end{array}$ & $72 \cdot 5$ & $61^{\star}$ & $75 \cdot 5$ & 76 & $(70 \cdot 5)$ & $75 \mathrm{NS}$ \\
\hline $\begin{array}{l}\text { CD4 + cells } \\
\text { (\% of lymphocytes) }\end{array}$ & $45 \cdot 5$ & $36^{\star}$ & 48 & $49 \cdot 5$ & $(43 \cdot 5)$ & $51 \cdot 5^{\star}$ \\
\hline $\begin{array}{l}\text { CD8 }+ \text { cells } \\
\text { (\% of lymphocytes) }\end{array}$ & $26 \cdot 5$ & $29 \mathrm{NS}$ & 25 & 24 & $(25 \cdot 5)$ & $24 \cdot 5^{\star}$ \\
\hline $\begin{array}{l}\text { Activated T cells } \\
\text { (\% of lymphocytes) }(n=9)\end{array}$ & 4 & $6^{\star}$ & 6 & 7 & - & $6 \mathrm{NS}$ \\
\hline $\begin{array}{l}\text { Natural killer cells } \\
\text { (\% of lymphocytes) }\end{array}$ & $16 \cdot 5$ & $20^{\star}$ & $12 \cdot 5$ & $9 \cdot 5$ & (16) & $9 \cdot 5^{\star \star}$ \\
\hline B cells & $10 \cdot 5$ & $13^{\star}$ & $12 \cdot 5$ & 13 & $(12 \cdot 5)$ & $14 \cdot 5^{\star \star}$ \\
\hline $\mathrm{CD} 4+{ }^{\star} \mathrm{CD} 8$ & 1.83 & $1.45 \mathrm{NS}$ & $2 \cdot 00$ & $2 \cdot 10$ & $(1.95)$ & $2 \cdot 10^{\star \star}$ \\
\hline
\end{tabular}

(Results expressed as medians with two tailed $\mathrm{p}$ values for the comparison with baseline data (Wilcoxon's rank sum test); ${ }^{\star \star} \mathrm{p}<0.01 ;{ }^{\star} \mathrm{p}<0.05$; NS = not significant.)

in the few hours after a single dose of corticosteroid has been documented in the work described above, ${ }^{2-6}$ there is little information about the effects of longer term corticosteroid administration in people, and in particular we were unable to find any study of these longer term effects in the absence of disease. We therefore studied a group of healthy volunteers taking prednisolone.

\section{Methods}

Twelve healthy volunteers were recruited from among senior medical staff. Eight were men and the ages ranged from 31 to 50 years. None had contraindications to corticosteroid administration and all gave informed consent.

A pilot study in one volunteer showed the

Figure 1 Lymphocytes and subsets in 12 healthy volunteers, in relation to doses of prednisolone EC $20 \mathrm{mg}(\downarrow): 0$-in blood samples taken immediately before the next prednisolone dose and 24 hours after the previous dose; $\bigcirc$-in blood samples taken 7 hours after the initial prednisolone dose. Results expressed as medians + interquartile range.
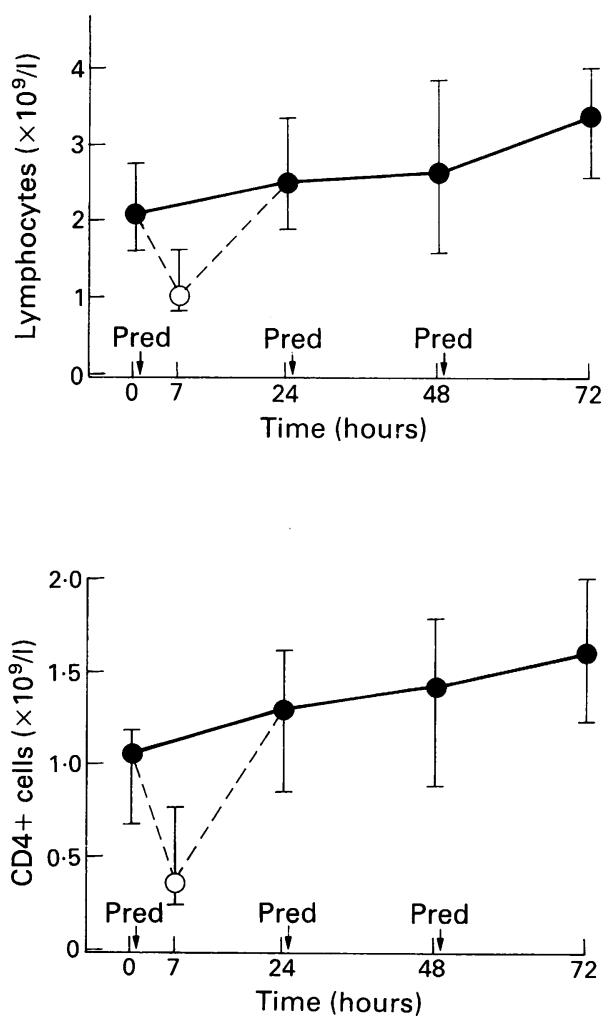

acute postdose effects on $T$ cell subsets to be maximal around seven hours after a dose of $20 \mathrm{mg}$ prednisolone enteric coated (EC), while in the longer term maximal effects were seen after three to four days of prednisolone administration. We therefore used a three day period of corticosteroid treatment in the volunteer group with blood tests taken over four days.

Each volunteer had baseline blood samples taken at 0900 hours and then took prednisolone EC $20 \mathrm{mg}$ daily orally at 0900 hours for three days. Further blood samples were taken at seven hours after the initial dose and again at 24,48 , and 72 hours -24 hours after the latest prednisolone dose, to avoid the acute postdose effects. Four volunteers also had blood samples taken at 55 hours-seven hours after the third dose of prednisolone.

All blood samples were processed within six hours of venesection. Total white cell counts and lymphocyte counts were measured using routine methods in the haematology department at Addenbrooke's Hospital. T cell subsets were analysed by flow cytometry using a whole blood lysis technique. Total $\mathrm{T}$ cell numbers were measured using anti-CD3 (Leu 4). Activated $T$ cells were those $\mathrm{CD} 3+$ cells which coexpressed anti-HLA-DR. CD4 + cells were defined by dual staining with anti-CD3 (Leu 4) and anti-CD4 (Leu 3), while CD8 + cells were defined using anti-CD3 with anti-CD8 (Leu 2). Natural killer cells were CD3- expressing CD16/56 (Leu 11c + 19). B cells were measured using anti-CD19. All monoclonal antibodies were purchased from Becton Dickinson (Oxford, England) from the Simultest range. Aliquots of blood were incubated with antibody pairs for dual staining for 15 minutes at room temperature.
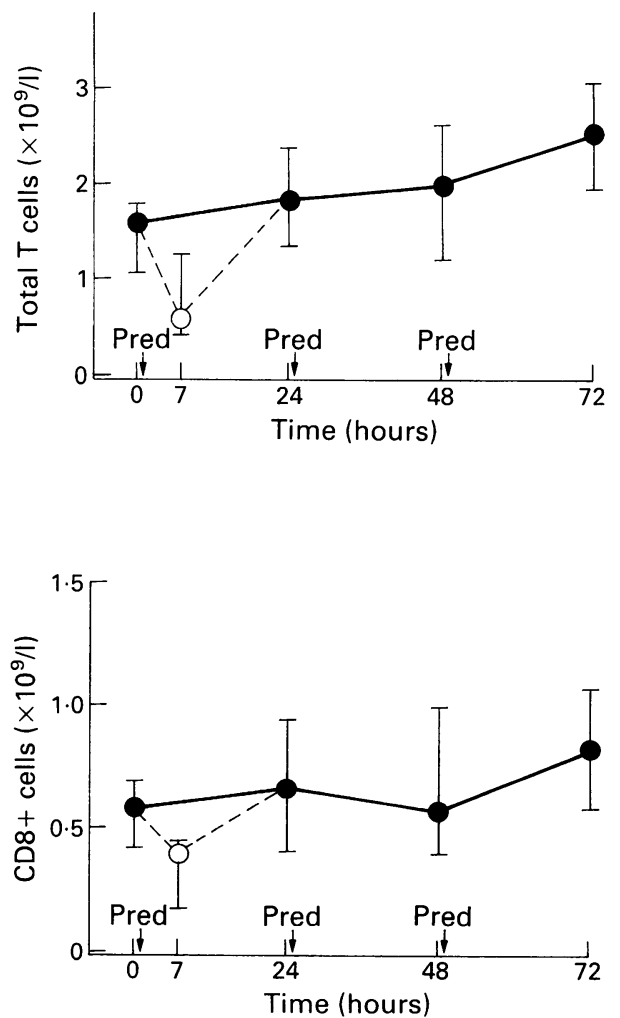
Figure 2 Change in percentage of $C D 8+$ cells after 72 hours of prednisolone

in 12 healthy volunteers, according to age.

$\square=$ men, $=$ women. Change in percentage of CD8 + cells expressed as percentage of lymphocytes. Spearman's rank correlation coefficient $=-0.599$ (two-tailed $p<0.05)$.

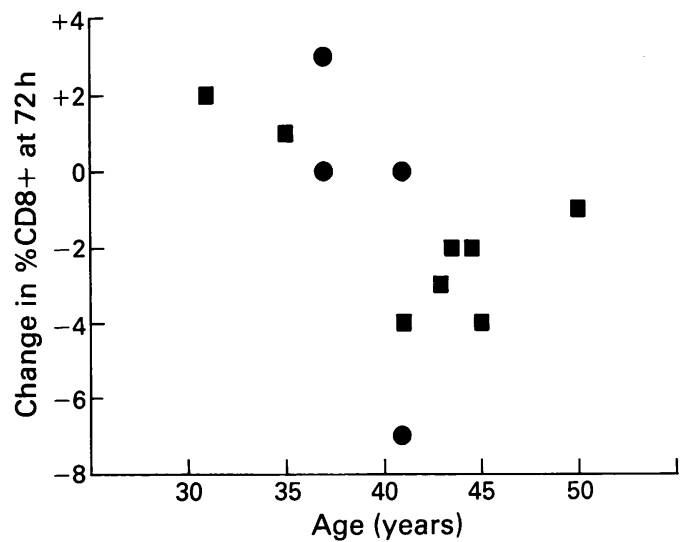

Erythrocytes were lysed using FACS lysing solution (Becton Dickinson) and leucocytes were fixed with $0.5 \%$ formaldehyde. Cells were analysed on the day of processing using a Becton Dickinson FACscan, and Simulset software.

The paired data for nought and seven hours and for nought and 72 hours were analysed using Wilcoxon's rank sum test.

\section{Results}

The changes in lymphocyte subsets during prednisolone treatment are shown in the table. The absolute numbers of lymphocytes, $\mathrm{T}$ cells, CD4,$+ \mathrm{CD} 8+$ and $\mathrm{B}$ cells had all fallen significantly by seven hours after the first dose of prednisolone, and by contrast had all risen significantly higher than baseline numbers at 72 hours ( 24 hours after the third dose of prednisolone) (fig 1).

As a percentage of total lymphocytes, $\mathrm{CD} 4+$ cells fell at seven hours, then rose significantly (table). The percentage of CD8+ cells did not change significantly at seven hours but was significantly lowered at 72 hours. This change was small. An unexpected finding was the more pronounced fall in the percentage of CD8 + cells by 72 hours in the older compared with the younger volunteers (fig 2). The Spearman rank order correlation coefficient was -0.599 (two-tailed test, p < $0.05)$. No correlation was seen in this study between age and the baseline percentage of $\mathrm{CD} 8+$ cells. No substantial difference in $\mathrm{T}$ cell changes was observed between men and women, but the number of women was too small for separate statistical analysis.

Values of lymphocyte subsets at 55 hours (seven hours after the third dose of prednisolone) are shown in the table, although the data were drawn from only four subjects. These values were intermediate between the seven hour and 72 hour values as might be expected, but the net effects were closer to the longer term effects-that is, the acute postdose effects are partially masked.

\section{Discussion}

This study of the effects of prednisolone on circulating lymphocyte subsets describes new findings. We have shown that the effects of continuing prednisolone administration beyond 24 hours in healthy volunteers results in effects which contrast strongly with the changes described in the first few hours after a single dose of prednisolone. These longer term effects were consistent with the changes we have observed in patients treated with prednisolone for PMR/GCA. ${ }^{1}$ Ferrari et $a l^{7}$ showed a similar rise in absolute numbers of lymphocytes, $\mathrm{T}$ cells, and CD4 + cells in patients with ITP treated with corticosteroids for four weeks, but they did not find a significant difference in the percentage of $\mathrm{CD} 4+$ or CD8 + cells.

Seven days of corticosteroid given to guinea pigs seem to produce different changes from those seen in studies in man. Fauci $^{8}$ observed a fall in lymphocytes and $\mathrm{T}$ cells in guinea pigs which persisted from the acute stage to seven days. Therefore, there seems to be a species difference in the effects of long term corticosteroids on lymphocytes and subsets.

The changes we have shown seven hours after the first dose of prednisolone have confirmed the findings in the controlled studies of ten Berge et al ${ }^{4}$ and Tonnesen et al. ${ }^{5}$ These authors described decreased absolute numbers of lymphocytes, T cells, CD4 + and CD8 + cells a few hours after a single dose of corticosteroid. We have also shown a short term fall in the percentage of CD4 + cells.

Circadian variation in lymphocyte subsets has been shown..$^{10}$ Ritchie et $a l^{9}$ described peak numbers of T cells, CD4 + and CD8 + cells at 2200 hours with an inverse correlation to plasma cortisol concentrations. Levi et al, ${ }^{10}$ however, found the peak of $T$ cells and CD4 + cells around 0200 hours, with no association with plasma cortisol values, even allowing for possible delayed hormonal action. So the role of endogenous cortisol in the diurnal changes in $T$ cell subsets is not clear. It is perhaps not surprising that such physiological effects, if present, may be less pronounced than the pharmacological effects of corticosteroids.

In Cushing's disease absolute numbers of $T$ cells are greatly decreased. ${ }^{11}$ This does not necessarily conflict with our finding of raised $T$ cells numbers in volunteers and in patients with PMR/GCA patients during long term prednisolone. ${ }^{1}$ In Cushing's disease the high circulating concentration of cortisol is sustained and may be equivalent to the acute postdose effects we have seen (a fall in $T$ cells), but persistent. In constrast to the sustained cortisol concentration in Cushing's disease, daily administration of prednisolone produces fluctuating blood concentrations, and the pre-dose samples used in our studies would contain low corticosteroid concentrations. At this stage the longer term effects of the corticosteroids would be evident, in the absence of the postdose effects.

Possible mechanisms for the changes are debatable. The acute reduction in circulating lymphocytes and T cells after a dose of prednisolone is too rapid to be attributable to an effect on lymphocyte proliferation. The 
absence of fever and rigors, as seen when lymphocytes are depleted using monoclonal antibodies, suggests that cell lysis is not involved. The most likely explanation seems to be a change in lymphocyte trafficking, with sequestration in the lymphoid organs. In guinea pigs this has been shown to be due to redistribution to the bone marrow. ${ }^{8}$ In the longer term, the rise in circulating lymphocytes and $T$ cells probably also reflects redistribution of the lymphocytes, but other mechanisms cannot be ruled out.

Our results suggest that the older subjects had a more pronounced fall in percentage of $\mathrm{CD} 8+$ cells with prednisolone, and in fact the youngest subjects actually had a slight rise in the percentage of CD8 + cells. There was no age dependent difference in baseline percentage of CD8 + cells in our study, although a decrease has been described in subjects over 60 years old ${ }^{12}$ and over 75 years. ${ }^{13}$ The numbers in our study were small and the age range was narrow (31-50 years), but if only older subjects respond to prednisolone with a decrease in the percentage of $\mathrm{CD} 8+$ cells, this would account for the observation of a fall in percentage of CD8 + cells in patients with PMR/GCA receiving prednisolone treatment, whose age ranged from 51-87 years (median 70 years). ${ }^{1}$ Ferrari et $a l^{7}$ found no significant change in CD8 + cells in patients with ITP receiving prednisolone treatment, where the age range was 15-57 years (median 32 years). One possible mechanism for the changing responsiveness to corticosteroids with age might be the changing numbers of corticosteroid receptors. Armanini et $a^{14}$ have described reduced corticosteroid receptors on mononuclear leucocytes in aged subjects (62-97 years), but in vitro glucocorticoid sensitivity does not seem to be related to numbers of corticosteroid receptors. ${ }^{15}$ Further studies are required in volunteers and patients over a wide range of ages to clarify the $T$ cell effects of corticosteroids in different age groups. We are now undertaking these studies.

The contrasting short term and longer term effects of corticosteroids shown in this study indicate the importance of controlling for corticosteroid effects in addition to circadian variation in all future studies of lymphocyte subsets.

We thank the volunteers for donating their time and blood, the MLSOs of the clinical immunology laboratory for measurement of lymphocyte subsets, and Mrs Sheila Smith for typing the manuscript.

1 Pountain GD, Keogan MT, Brown DL, Hazleman BL. Circulating $T$ cell subtypes in polymyalgia rheumatica and giant cell arteritis: \% CD8 + cells are not reduced until prednisolone treatment commences. Ann Rheum Dis 1993;52:730-3.

2 Yu DTY, Clements PJ, Paulus HE, Peter JB, Levy J. Human lymphocyte subpopulations: effect of corticosteroids. $\mathscr{f}$ Clin Invest 1974;53:565-71.

3 Fauci AS. Mechanism of corticosteroid action on lymphocyte subpopulations. II. Differential effects of in vivo hydrocortisone, prednisolone and dexamethasone on in hydrocortisone, prednisolone and dexamethasone on in
vitro expression of lymphocyte function. Clin Exp vitro expression of lym

4 ten Berge RJM, Sauerwein HP, Yong SL, Schellekens PTA. Administration of prednislone in vivo affects the ratio of OKT4/OKT8 and the LDH-isoenzyme pattern of human $\mathrm{T}$ lymphocytes. Clin Immunol Immunopathol 1984;30:91-103.

5 Tonnesen E, Christensen NJ, Brinklov MM. Natural killer cell activity during cortisol and adrenaline infusion in healthy volunteers. Eur $f$ Clin Invest 1987;17: in healthy

6 Hogevold HE, Lyberg T, Reikeras O. Changes in leukocyte subpopulations following total hip replacement surgery. Effects of high dose corticosteroids. Scand $\mathcal{F}$ Clin Lab Invest 1991;51:443-51.

7 Ferrari A, Pasqualetti D, del Bianco P, Gandolfo GM, Chistolini A, Mazzucconi MG. Prednisolone versus deflazacort in the treatment of autoimmune thrombocytopenia purpura: evaluation of clinical response and immunological modifications. Haematologica 1991;76: 342-5.

8 Fauci AS. Mechanisms of corticosteroid action on lymphocyte subpopulations. I. Redistribution of circulating $\mathrm{T}$ and $\mathrm{B}$ lymphocytes to the bone marrow. Immunology 1975;28:669-80.

9 Ritchie AWS, Oswald I, Micklem HS, et al. Circadian variation of lymphocyte subpopulations: a study with monoclonal antibodies. $\operatorname{BrMed} \mathcal{f} 1983 ; 286: 1773-5$.

10 Levi FA, Canon C, Touitou Y, et al. Circadian rhythms in circulating $T$ lymphocyte subtypes and plasma testosterone, total and free cortisol in five healthy men. Clin Exp Immunol 1988;71:329-35.

11 Shohat B, Klein A, Kaufmann H, Blum I, Chowers I. T lymphocytes and plasma inhibitory factor in ACTHdependent Cushing's patients. Clin Immunol Immunopathol 1979;13:452-61.

12 Nagel JE, Chrest FJ, Adler WH. Enumeration of T lymphocyte subsets by monoclonal antibodies in young and phocyte subsets by monoclonal antibodies in
aged humans. F Immunol 1981;127:2086-8.

13 Ligthart GJ, Schuit HRE, Hijmans W. Subpopulations of mononuclear cells in ageing: expansion of the null cell compartment and decrease in the number of $T$ and $B$ cells in human blood. Immunol 1985;55:15-21.

14 Armanini D, Karbowiak I, Scali M, Orlandini E, Zampollo V, Vittadello G. Corticosteroid receptors and lymphocyte subsets in mononuclear leukocytes in ageing. Am $\mathcal{F}$ Physiol 1992;262:3464-6.

15 Smith KA, Crabtree GR, Kennedy SJ, Munck A. Glucocorticoid receptors and glucocorticoid sensitivity of mitogen-stimulated and unstimulated human lymphocytes. Nature 1977;267:523-6. 